\title{
Sumbangan Pemikiran Jhon. F Haught mengenai Relasi Sains dan Agama
}

\author{
Hakin Najilii ${ }^{1}$ Nanat Fatah Natsir ${ }^{2}$, Erni Haryanti ${ }^{3}$ \\ 1,2,3Universitas Islam Negeri Sunan Gunung Djati Bandung, Indonesia \\ E-mail: hakinnajili35@gmail.com, nanatfatahnatsir@uinsgd.ac.id, erni_hk@uinsgd.ac.id
}

\begin{tabular}{l} 
Article Info \\
\hline Article History \\
Received: $2021-11-20$ \\
Revised: $2021-12-15$ \\
Published: $2022-01-14$
\end{tabular}

Published: 2022-01-14

Keywords:

Idea;

John F Haught;

Science;

Religion.

\begin{abstract}
This study explains the contribution of Jhon F Haught's thoughts on the relationship between science and religion. The method used in this study uses a library research method or approach, that library research can be interpreted as a series of activities related to the methods of collecting library data, reading and taking notes and processing research materials. The results of this study indicate that John F Haught "sees" and "interprets" the integration of science and religion as "two faces of epistemology" that touch each other and give rise to enlightening complementarity. It shows how science and religion are dug into the depths so that each will meet at the same estuary. Haught's courage to collaborate on evolution for the sake of religious compatibility is a courage because such a reading necessitates a theological shift. Haught's integration model gave birth to evolutionary theology which is a modern reconstructionist "faced" epistemology-theological building that takes religion so far for its compatibility with the development of science. In other words, theology becomes the benchmark for these scientific theories by including Islamic entities in the structure of science.
\end{abstract}

\begin{tabular}{l}
\hline Artikel Info \\
\hline Sejarah Artikel \\
Diterima: 2021-11-20 \\
Direvisi: 2021-12-15 \\
Dipublikasi: 2022-01-14
\end{tabular}

Kata kunci:

Pemikiran;

Jhon F Haught;

Sains;

Agama.

\begin{abstract}
Abstrak
Penelitian ini menjelaskan tentang sumbangan pemikiran Jhon F Haught mengenai relasi sains dan agama. Metode yang digunakan dalam kajian ini menggunakan metode atau pendekatan kepustakaan (library research), bahwa studi pustaka atau kepustakaan dapat diartikan sebagai serangkaian kegiatan yang berkenaan dengan metode pengumpulan data pustaka, membaca dan mencatat serta mengolah bahan penelitian. Hasil penelitian ini menunjukkan bahwa Jhon F Haught "melihat" dan "memaknai" integrasi sains dan agama sebagai "dua wajah epistemologi" yang saling bersentuhan dan memunculkan sifat komplementasi yang mencerahkan. Ini menunjukkan bagaimana sains dan agama digali menuju kedalaman sehingga masingmasing akan bertemu pada muara yang sama. Keberanian Haught untuk mengolaborasi evolusi demi kompatibilitas agama merupakan satu keberanian karena pembacaan semacam itu meniscayakan adanya pergeseran teologis. Model integrasi Haught melahirkan teologi evolusi yang merupakan sebuah bangunan epistemologiteologis "berwajah" rekonstruksionis modern yang membawa agama begitu jauh demi kesesuaiannya dengan perkembangan sains. Dengan kata lain, teologi menjadi tolak ukur teori-teori ilmiah tersebut dengan memasukkan entitas keislaman pada struktur sains.
\end{abstract}

\section{PENDAHULUAN}

Sains dan agama pada hakekatnya memiliki prinsip dan pembenaran sendiri sehingga sering terjadi perbedaan pendapat diantara keduanya. Perkembangan ilmu pengetahuan khususnya sains berjalan dengan sangat cepat. Sementara itu, pemahamaman yang terkait dengan sains yang mendasar pada keimanan berjalan lebih lambat. Banyak ilmuan yang beragument bahwa semua penelitian dilakukan dengan langkah yang dapat dipertanggungjawabkan, sebaliknya para agamawan lebih banyak membicarakan persoalan akhirat dan pesan-pesan moral. Maka dari itu sering terjadi benturan antara ilmu pengetahuan khususunya sains dengan ilmu agama.
Menurut Mukti Ali, tidak ada kata yang paling sulit untuk mendevinisikan selain dari kata agama. Pernyataan ini didasarkan kepada tiga alasan. Pertama bahwa pengalaman agama adalah soal batiniah, subjektif dan sangat individualis sifatnya. Kedua, ada yang bersemangat dan emosional dalam membicarakan agama, karena itu setiap pembahasan tentang agama selalu ada emosi yang melekat erat sehingga kata agama sulit didefinisikan. Ketiga, konsepsi tentang agama dipengaruhi oleh tujuan dari orang yang memberikan definisi tersebut (Haught, 2004b), agama berasal dari kata religi (Inggris), religere (Belanda), din (Arab). Secara etimologis dapat diartikan keselarasan, tidak kacau tatanan 
terhadap sesuatu, peraturan-peraturan tradisional, ajaran-ajaran, kumpulan-kumpulan hukum yang turun temurun dan ditentukan oleh adat kebiasaan. Adapun secara ontologis hakikat agama berarti sesuatu yang tidak nampak atau abstrak. Bila makna agama ditangkap dari aspek yang nampak, ia akan berwujud sebagai simbol ritual yang dilakukan oleh umat beragama. Misalnya dalam peristiwa Asyura, ngaben, dan sebagainya. Sementara itu, makna abstrak dapat dipahami dari sisi konseptual seperti dalam perspektif teologis, agama diartikan sebagai kepercayaan terhadap Tuhan yang selalu hidup, yaitu kepada jiwa dan kehendak Ilahi yang mengatur alam semesta dan mempunyai hubungan moral dengan umat manusia (Haught, 2000).

Pada dasarnya sains tidak dimaksudkan untuk menjawab semua hal yang ada dalam kehidupan ini. Hal yang membuat sains begitu berharga, karena sains membuat kita belajar tentang diri kita sendiri. Oleh sebab itu, diperlukan kearifan dan kerendahan hati untuk dapat memahami dan melakukan interpretasi maupun implementasi ilmu sains (Arifudin, 2021). Bahkan Albert Einstein pun pernah dalam salah satu pidatonya berkata bahwa ilmu pengetahuan tanpa agama akan lumpuh dan agama tanpa ilmu pengetahuan akan buta, dan perlu diketahui pergelutan Einstein dengan sains membuatnya menemukan Tuhan, sains secara etimologis berasal dari scire (Latin) berarti mengetahui, keadaan atau fakta mengetahui atau pengetahuan (Knowledge) yang dikontraskan dengan intuisi atau kepercayaan. Secara ontologis, sains merupakan pengetahuan sistematis yang berasal dari observasi, kajian dan percobaan yang dilakukan untuk menentukan sifat dasar atau prinsip apa yang dikaji.

Sains adalah pengetahuan mengenai fenomena-fenomena spasiotemporal atau alam semesta pada umumnya, seperti kimia, fisika, dan astronomi. Menurut (Febrianty, 2020) bahwa sains merupakan salah satu bentuk pengetahuan manusia yang gigih mencari makna. Sains berusaha menjelaskan tentang apa dan bagaimana alam sebenarnya dan bagaimana teori ilmu pengetahuan dapat menjelaskan fenomena yang terjadi di alam. Untuk tujuan tersebut, sains menggunakan bukti dari eksperimen, deduksi logis, dan atau pemikiran rasional untuk mengamati alam dan individual dalam suatu masyarakat (Arifudin, 2020).

Menurut Eisnstein, sains merupakan pemikiran metodik yang diarahkan untuk menemukan hubungan regulatif antara pengalaman pengalaman sensual manusia. Dalam waktu relatif cepat, sains menghasilkan pengetahuan dan secara tidak langsung merupakan alat bertindak menuju ke tindakan yang metodikal apabila tujuantujuan tertentu telah ditetapkan sebelumnya. Perkembangan selama ini menunjukkan bahwa sains didominasi oleh aliran positivisme, yaitu aliran yang sangat mengutamakan metode ilmiah dengan menempatkan asumsi asumsi metafisis, aksiologis. Menurut aliran ini, sains mempunyai reputasi tinggi untuk menentukan kebenaran (Waston, 2014).

Penganut aliran ini, mengatakan bahwa sains mempunyai reputasi tinggi untuk menentukan kebenaran dan sains merupakan "dewa" dalam beragam tindakan (sosial, ekonomi, politik, dan lain-lain). Sedangkan menurut mereka, agama hanyalah merupakan hiasan belaka ketika tidak sesuai dengan sains, begitu kira-kira kata kaum positivisme.

Perkembangan sains bisa dikatakan sejajar dengan perkembangan zaman. Sementara agama, ditempatkan sebagai sesuatu yang relatif tidak berubah. Pertemuan antara keduanya memungkinkan terjadinya ketegangan dengan perubahan yang terus menerus. Secara umum, persoalannya adalah bagaimana memahami hal-hal yang tak berubah (agama) dalam konteks yang selalu berubah (sains). Pertentangan yang terjadi di dunia Barat sejak berabad lalu sesungguhnya disebabkan oleh paradigma yang keliru dalam memaknai hakikat sains dan agama. Kepercayaan agama menawarkan kerangka makna yang lebih luas dalam kehidupan. Sedangkan sains tidak dapat mengungkap rentang yang luas dari pengalaman manusia atau mengartikulasikan kemungkinan-kemungkinan bagi tranformasi hidup manusia sebagaimana yang dipersaksikan oleh agama (Haught, 2000). Agama dan sains memiliki metode sendiri-sendiri. Metode ini menjadi tajam ketika dibahas oleh ahlinya, yaitu para teolog dan juga para ilmuwan. Keduanya mempunyai kedudukan sama kuat dan saling mempengaruhi (Leksono, 2003).

Sains merupakan karunia pada manusia yang tak tertandingi sepanjang zaman, sementara itu sains juga merupakan salah satu jalan untuk mencari kebenaran, yaitu kebenaran obyektif (Na'im, 2021). Sedangkan penerapan sains dalam dunia modern diakui telah menghasilkan banyak teknologi yang membuat kehidupan manusia lebih nyaman dan aman. Walaupun begitu, sains cenderung menjadi otonom sehingga karenanya ia lebih sering dipandang sebagi satu-satunya jalan menuju kebenaran, sehingga sebagai akibatnya kita sering menghadapi benturan 
antara sains dan agama. Persoalannya sains sebenarnya hanya berbicara tentang realitas obyektif tentang alam dan manusia, padahal sesungguhnya agama berbicara tentang manusia seutuhnya yaitu tubuh, ruh dan alam yang luas, yaitu alam nyata dan alam ghaib, serta kenyataan seluruhnya, yaitu alam beserta Tuhan Yang Maha Pencipta. Sebenarnya terdapat integrasi antara keduanya, yaitu pada masalah manusia dan alam sehingga sebenarnya tidak ada pertentangan diantara keduanya.

Namun dalam perjalanan sejarahnya beberapa abad setelah renaisans, revolusi sains diikuti revolusi industri dan revolusi informasi. Pengetahuan ilmiah manusia tentang diri dan alam lingkungan kita telah berubah secara tajam, sama sepeti perubahan pandangan terhadap agama, karena itulah agama makin ditinggalkan. Hal ini terjadi jika kita hanya melihat pada tataran permukaan saja, padahal seharusnya kita melihat bahwa sebenarnya teologi hanyalah merupakan konstruksi intelektual manusia yang mencoba memahami pesan-pesan religius para nabi. Dengan demikian, manusia perlu menghadapkan teologi dengan sains, dan membuat keduanya berkembang secara dialektis dan komplementer untuk memecahkan permasalahan umat manusia yang ditimbulkan oleh penerapan sains yang semakin maju.

Hubungan sains dan agama adalah hubungan yang rumit. Pertautan keduanya dalam sejarah mengalami benturan-benturan. Peristiwa saling menghakimi satu sama lain pun terjadi secara kontinu. Hingga kini, upaya memadukan sains dan agama terus menerus dilakukan oleh berbagai tokoh dan berkembang di berbagai negara, termasuk Indonesia. Sejarah telah mencatat, Gereja Katolik pada tahun 1992 di bawah kepemimpinan Paus Johannes Paulus II telah mengakui kebenaran teori Galileo setelah ratusan tahun yang lalu disalahkan oleh dewan inkuisisi Gereja. Sebuah pertanda terhapusnya permusuhan sains dan agama. Hubungan antara agama dan sains selalu menjadi wacana diskusi yang menarik. Sains dalam kehidupan manusia selalu berkembang dan berubah. Sedangkan agama selalu dianggap tradisi turun temurun yang dipertahankan oleh masyarakat tertentu. Sains dan teknologi saat ini mencapai perkembangan yang sangat pesat, bahkan seolah tidak pernah terprediksikan sebelumnya. Sejak revolusi keilmuan terhadap otoritas keagamaan pada abad ke 12-13. Sejak saat itulah sains memisahkan diri dari otoritas keagamaan Kristen. Sains dan teknologi di Barat seperti mesin uap, komp- uter, mekanika, dan lainnya mengalami perkembangan pesat pada abad ke17-18.

Negara-negara yang saat ini sangat berkontribusi dalam sains dan teknologi mayoritas merupakan negara-negara Barat (Irwansyah, 2021). Hal ini sudah menjadi fakta yang empiris, dari segi penelitian dan akademik. Perkembangan sains juga diikuti oleh perkembangan paradigma manusia yang ada. Dalam dunia modern sekarang ini sains merupakan karunia tak tertandingi sepanjang zaman bagi kehidupan manusia dalam menghadapi segala tuntutan dan perkembangannya (Mayasari, 2021). Dan sudah menjadi kebutuhan manusia yang ingin mencapai kemajuan dan kesejahteraan hidup, untuk menguasai dan memanfaatkan sains sebagai prasyarat bagi kelangsungan hidupnya. Pesatnya kemajuan ilmu pengetahuan dan teknologi sebagai hasil aplikasi sains tampak jelas memberikan kesenangan bagi kehidupan lahiriah manusia secara luas, dan manusia telah mampu mengeksploitasi kekayaan-kekayaan dunia secara besar-besaran. Permasalahannya adalah pesatnya kemajuan itu sering diikuti dengan merosotnya kehidupan beragama. Perkembangan sains dan teknologi bukan tanpa masalah. Banyak penelitian yang mendalam mengenai dampak jangka panjang dari pesatnya perkembangan sains tersebut. Dari paparan tersebut, muncul adanya ide untuk mensintesakan ajaran-ajaran dan etika yang ada pada agama ke dalam aktifitas saintifik untuk mengendalikan perkembangan teknologi tersebut.

Para saintis dan agamawan di Amerika pernah mendiskusikan perlunya integrasi sains dan agama. Penggunaan ilmu pengetahuan dan teknologi yang tidak dibatasi dengan moral dan etika, sudah terbukti banyak merugikan kehidupan manusia. Manusia membutuhkan pedoman berupa nilai moral dalam perkembangan teknologi tersebut (Sofyan, 2020). Keberlangsungan hidup manusia tidak terlepas dari ilmu. Di sisi lain, juga diperlukan agama untuk mengisi sisi spiritual, memberikan ketenangan, serta tuntunan bagi manusia dalam berhubungan dengan Allah yang Maha Pencipta dan dalam berhubungan dengan manusia lainnya. Segala sesuatu yang dipikirkan dan dikerjakan oleh umat manusia adalah berkaitan dengan pemenuhan kebutuhan dan dan kebahagian. Upaya pemenuhan kebutuhan dan kebahagian tersebut dicapai melalui ilmu dan pengetahuan yang terus berkembang (Tanjung, 2020).

Peneliti akan mencoba menelisik dimensi integrasi dengan membongkar pemikiran tohoh 
yang sangat berpengaruh saat ini. Tokoh tersebut adalah John F. Haught adalah seorang teolog Kristen dari Amerika Serikat yang sering disebut sebagai salah satu tokoh teolog sistematis terkemuka. Pilihan atas Haught saat ini keduanya mempunyai pengaruh yang sangat kuat dalam diskursus wacana integrasi. Disamping itu tokoh tersebut cukup realistis dalam meletakkan agama ketika bersinggungan dengan sains. Tokoh ini mengikuti perkembangan sains dengan seksama namun pada saat yang bersamaan tetap bersikap kritis dan menjadi manusia-manusia yang religius. Hal semacam itu berbeda dengan pemikiran-pemikiran yang cenderung mencoba memaksakan sains untuk kembali dalam bentuknya yang masih murni seperti yang diidealkan Seyyed Hossein Nasr. Haught lulus dari St. Mary Seminary University di Baltimore dan kemudian menerima gelar PhD dalam bidang teologi dari The Catholic University of America pada tahun 1970. Haught adalah pemenang Owen Garrigan Award pada Sains dan Agama pada tahun 2002 dan Sophia Award 2004 untuk Theological Excellence. Selain itu, pada tahun 2009, sebagai pengakuan atas karyanya pada teologi dan sains, Haught dianugerahi gelar Doktor Honoris Causa oleh University of Leuven (Barbour, 2000).

Dengan latar semacam itu diharapkan proyek integrasi sains (ilmu) dan agama menjadi pekerjaan besar yang berarah ke depan (futuristic orientation). Secara komprehensif akan diuraikan beberapa hal mendasar yang menjadi pemikiran Haught Untuk mempermudah pelacakan, pada setiap tokoh, akan didekati dengan mengupas empat hal prinsipil; pertama, akan diperlihatkan bagaimana agama dan sains dimaknai oleh masing-masing tokoh dan apa yang terjadi ketika agama harus bertemu dengan sains; apakah agama melihat sains dengan kaca mata bermusuhan (konflik), saling menyendiri tapi tidak bermusuhan, saling bertegur sama, atau bahkan saling melebur dan menyatukan diri?. Kedua, menyisir asumsi-asumsi dasar yang digunakan J. F Haught maupun dalam mengintegrasikan sains dan agama. Asumsi-asumsi tersebut adalah bagian penting yang bisa mengintegrasikan justifikasi-justifikasi seintifik dengan uraian-uraian agama. Ketiga, akan dikupas bentuk nyata dari integrasi dimana Haught menawarkan teologi evolusi (theology of evolution) Dan keempat, yaitu mengaitkan sekaligus memadukan pemikiran dalam konteks pendidikan Islam yang memiliki komitmen terhadap pengembangan nilai-nilai Islam dalam pentas peradaban dunia.

\section{METODE PENELITIAN}

Sesuai dengan karakteristik masalah yang diangkat dalam penelitan ini maka menggunakan Metode Riset kualitatif, yaitu menekankan analisanya pada data deskriptif berupa kata-kata tertulis yang diamati. Pendekatan kualitatif penulis gunakan untuk menganalisis sumbangan pemikiran Jhon F Haught mengenai relasi sains dan agama.

Maka dengan sendirinya penganalisaan data ini lebih difokuskan pada Penelitian Kepustakaan (Library Research), yakni dengan membaca, menelaah dan mengkaji buku-buku dan sumber tulisan yang erat kaitannya dengan masalah yang dibahas. Metode yang digunakan dalam kajian ini menggunakan metode atau pendek-atan kepustakaan (library research), menurut Zed dalam (Rahayu, 2020) bahwa studi pustaka atau kepustakaan dapat diartikan sebagai seran-gkaian kegiatan yang berkenaan dengan metode pengumpulan data pustaka, membaca dan mencatat serta mengolah bahan penelitian.

Jenis penelitian ini adalah penelitian kualitatif. Menurut Ibnu dalam (Nasser, 2021) penelitian kualitatif adalah suatu penelitian yang datanya dinyatakan dalam bentuk verbal dan dianalisis tanpa menggunakan teknik statistik. Berdasarkan beberapa definisi penelitian kualitatif di atas, dapat disimpulkan bahwa penelitian kualitatif adalah suatu penelitian yang datanya dinyatakan dalam bentuk verbal, tidak menggunakan angka dan analisisnya tanpa menggunakan teknik statistik.

1. Objek Penelitian

Dalam penelitian ini objek penelitian terdiri dari 2 (dua), yaitu objek formal dan objek material (Hasbi, 2021). Objek formal dalam penelitian ini berupa data yaitu data yang berhubungan dengan tinjauan kritis terhadap sumbangan pemikiran Jhon F Haught mengenai relasi sains dan agama. Sedangkan objek materialnya berupa sumber data, dalam hal ini adalah tinjauan kritis terhadap sumbangan pemikiran Jhon $F$ Haught mengenai relasi sains dan agama.

2. Waktu Penelitian

Penelitian ini dilaksanakan pada bulan Oktober sampai dengan Desember tahun 2021.

3. Teknik Pengumpulan Data

Pengumpulan data yang dilakukan dengan menggunakan teknik dokumentasi yaitu mengadakan survey bahan kepustakaan untuk 
mengumpulkan bahan-bahan, dan studi literatur yakni mempelajari bahan-bahan yang berkaitan dengan objek penelitian. Teknik pengumpulan data menurut (Bahri, 2021) mengemukakan bahwa merupakan langkah yang paling strategis dalam penelitian karena tujuan untama dari penelitian adalah mendapatkan data. Terdapat beberapa cara atau teknik dalam mengumpulkan data, diantaranya adalah observasi dan dokumentasi. Sumber data yang digunakan dalam penelitian ini mencakup data primer dan sekunder. Menurut (Hanafiah, 2021) bahwa data primer adalah data yang dikumpulkan langsung dari individu-individu yang diselidiki atau data tangan pertama. Sedangkan data sekunder adalah data yang ada dalam pustaka-pustaka. Data primer dalam penelitian ini adalah bukubuku terkait tinjauan kritis terhadap sumbangan pemikiran Jhon $F$ Haught mengenai relasi sains dan agama, dan data sekunder didapatkan dari jurnal-jurnal baik nasional maupun internasional.

4. Alat Pengumpulan Data

Dalam penelitian ini, penulis akan menggunakan metode dokumentasi sebagai alat untuk pengumpul data karena penelitian ini adalah penelitian kepustakaan. Dengan kata lain, menurut (Juhji, 2020) bahwa teknik ini digunakan untuk menghimpun data-data dari sumber primer maupun sekunder.

5. Teknik Analisis Data

Analisis data tidak saja dilakukan setelah data terkumpul, tetapi sejak tahap pengumpulan data proses analisis telah dilakukan. Penulis menggunakan strategi analisis "kualitatif", strategi ini dimaksudkan bahwa analisis bertolak dari data-data dan bermuara pada kesimpulan-kesimpulan umum. Berdasarkan pada strategi analisis data ini, dalam rangka membentuk kesimpulan-kesimpulan umum analisis dapat dilakukan menggunakan kerangka pikir "induktif". Menurut (Sugiyono, 2015) bahwa metode pembahasan menggunakan metode deskriptif-analisis, yaitu menjelaskan serta mengelaborasi ide-ide utama yang berkenaan dengan topik yang dibahas. Kemudian menyajikannya secara kritis melalui sumber-sumber pustaka primer maupun skunder yang berkaitan dengan tema.

6. Prosedur Penelitian

Data pada penelitian ini dicatat, dipilih dan kemudian diklasifikasikan sesuai dengan kategori yang ada. Pendekatan yang digunakan adalah pendekatan deskriptif analitis.
Menurut (Marantika, 2020) bahwa deskriptif analitis (descriptive of analyze research), yaitu pencarian berupa fakta, hasil dari ide pemikiran seseorang melalui cara mencari, menganalisis, membuat interpretasi serta melakukan generalisasi terhadap hasil penelitian yang dilakukan. Prosedur penelitian ini adalah untuk menghasilkan data deskriptif yang berupa data tertulis setelah melakukan analisis pemikiran (content analyze) dari suatu teks. Setelah penulis mengumpulkan bahan-bahan yang berhubungan dengan masalah yang akan di bahas dalam penelitian ini, kemudian penulis menganalisis dan menarasikan untuk diambil kesimpulan.

\section{HASIL DAN PEMBAHASAN}

Dalam pembahasan ini akan dibahas tentang Analisis Sikap Agama atau Teologi terhadap Sains, Landasan Integratif Sains dan Agama, Bentuk Integratif Sains dan Agama (Theology of Evolution), dan Titik Temu Pemikiran John F. Haught dalam Konstruksi Sains dan Agama.

1. Analisis Sikap Agama atau Teologi terhadap Sains

Haught membagi pola relasi sains dan agama dalam empat bentuk : konflik, kontras, kontak, dan konfirmasi. Relasi pertama menempatkan sains dan agama sebagai dua entitas yang berseberangan dari berbagai sudut, baik secara muatan (content), historis, maupun metodologis. Dalam pola relasi ini terjadi berjumpaan antara aliran skeptis ilmiah (scientific skeptics) sebagai kekuatan yang dengan keras menegaskan tidak diperlukannya lagi penjelasan- penjelasan agama dengan kelompok literal (Biblical literalist) yang memahami kitab suci sebagai satu-satunya sumber kebenaran. Perjumpaan dua kubu yang saling menegaskan tersebut memunculkan konflik yang tak kesudahan (Barbour, 2006).

Dalam relasi kontras, Haught menyarankan untuk membuat suatu batasan yang jelas antara sains dan agama sehingga tidak terjadi konflik. Batasan ini dimaksudkan sebagai penjelas bahwa masing-masing mempunyai wilayah yang berbeda, sehingga tidak boleh menjustifikasi agama, misalnya, dengan kategori-kategori yang dimiliki sains. Pola relasi kontras ini penting karena seringkali konflik muncul ketika terjadi peleburan (conflation), yakni runtuhnya perbedaan sains dan agama yang berakibat pada hilangnya 
unsur-unsur yang membedakan keduanya. Tentu saja, peleburan (conflation) ini terjadi, baik pada agama maupun sains. Kisah termartirkannya Galileo adalah kesalahan dalam mengidentifikasi wilayah agama yang dipaksakan pada sains.

Pola berikutnya adalah kontak, dengan relasi ini agama dan sains diarahkan untuk saling berkomunikasi tanpa menghilangkan batas-batas yang dimilikinya. Hal ini berangkat dari kenyataan yang ada dimana keduanya seringkali bertemu dan dikondisikan untuk saling mengungkapkan pendapat masing-masing (Abidin, 2005). Bentuk relasi terakhir yang secara jelas menunjukkan proyek utama John F. Haught adalah konfirmasi (confirmation). Ia mengartikan konfirmasi sebagai "menguatkan" atau "mendukung", bahwa agama menyokong penuh usaha-usaha yang dilakukan sains untuk memahami alam semesta. Pendek kata ia mengatakan: "Religion is in a very deep way supportive of the entire scientific enterprise." Bentuk konfirmasi agama terhadap sains bukan karena agama menyediakan seperangkat pengetahuan tentang semesta seperti yang ditawarkan oleh sains. Agama tidak mempunyai pengetahuan terinci tentang fisika partikel atau kode genetik. Sikap mendukung ini karena secara prinsipil pandangan-pandangan agama bahwa alam semesta terbatas, koheren, rasional, dan teratur, menyediakan pandangan umum yang secara konsisten memelihara pencarian ilmiah dan membebaskan sains dari segala bentuk ideologi yang memenjarakan (Haught, 1995).

Bagi Haught pencarian yang berbasis agama memunculkan kesadaran yang semakin tinggi jika dibandingkan dengan cara pandang materialis yang menghentikan pencarian hanya pada ranah kebendaan.

\section{Landasan Integratif Sains dan Agama}

Ketika Haught menyatakan bahwa agama mendukung sains dengan pola konfirmasinya, maka pertanyaan yang muncul adalah apa yang mendasari itu semua? Bangunan apakah yang bisa menjustifikasi bahwa sains mempunyai kaitan yang erat dengan agama? Dalam pandangan Haught sains tidak bisa memenuhi dirinya sendiri (self sufficient) dalam melakukan upaya-upaya ilmiah. Sains selalu merujuk atau mengakar pada keimanan (faith): "Science, to be more specific, cannot even get off the ground with out rooting itself in a kind of a priori "faith" that the universe is rationally ordered totally of things". (Haught, 1995)

Oleh karena itu sains tidak bisa berdiri sendiri, namun ia bergantung pada entitas yang sifatnya permanen tersebut. Haught mendefinisikan nilai permanen tersebut sebagai sumber inspirasi yang akhirnya menghidupkan dan mengembangkan lebih jauh eksplorasi ilmiah. Hal yang bersifat tetap dan selalu mendasari sains tersebut adalah "iman" (faith) bahwa alam semesta bersifat teratur (beserta hukum yang menyertainya) dan rasional. Dalam membangun sebuah bangunan yang integrative antara sains dan agama Haught menawarkan pembacaan epistemologis bahwa sains selalu mengakar pada iman yang di dalamnya agama memberi definisi yang sangat jelas. Sains mau tidak mau harus mengatakan bahwa eksistensinya sangat bergantung pada adanya keteraturan yang secara permanen ada dalam semesta. Bagi Haught di sanalah, "keimanan," mendapat makna ketika diasosiasikan dengan agama sebagai "semangat" keimanan. Schubert Ogden memahami agama sebagai "penjamin" (re-assurence), sebagai bagian paling mendasar untuk membangun kepercayaan diri ketika semangat itu hilang (Haught, 2003).

Meskipun ranah iman memang tidak disinggung secara absolut bahkan dipandang sebagai wilayah sains yang perlu mendapat perhatian karena keimanan tidak mempunyai basis epistemologis yang bisa diverifikasi dan dibuktikan kebenaranya secara empirismaterial, bagi Haught iman sangatlah penting untuk mencapai sebuah pengetahuan yang komprehensif. Iman dipahami sebagai kesadaran dimana manusia membuka dirinya untuk direngkuh oleh dimensi realitas yang lebih komprehensif dibandingkan akal fikiran. Melalui iman kesadaran manusia mengenali batasan yang menyertainya dan sekaligus mengantarkan pada pemahaman dimensi yang lebih tinggi (kompleks). Keimanan adalah sebuah jaminan agar relitas dapat dipahami lebih lanjut (Haught, 2004b). Singkat kata ia adalah langkah awal sekaligus sebagai hal pertama yang harus dimiliki sains agar bisa membuka rahasia realitas.

Selain fungsinya sebagai kategori pertama dari proses ilmiah, iman (faith) secara fundamental adalah entitas yang mampu membawa manusia menuju sebuah pengetahuan atau pemahaman yang komprehensif (menyeluruh). Ini terjadi karena kemampuan manusia 
yang terbatas dalam memahami realitas sehingga membutuhkan entitas yang diletakkan sebagai sumber pengetahuan. Seperti dinyatakan Haught, "Faith is an attitude of acknowledging the limits of comprehension and of opening ourselves to being comprehended by that which transcends us".

Oleh sebab sains tidak mampu mencapai sifat komprehensif ketika membatasi diri dalam ranah material semata. Sains harus melibatkan pengetahuan yang bersumber dari agama dan Tuhan sebagai wujud dari sifat transendensi. Akan tetapi sains cenderung mengindahkan entitas tersebut karena melihat iman (faith) sebagai pengetahuan yang tidak bisa diurai dengan prinsip- prinsip (metodologi) sains. Haught meyakinkan bahwa kehadiran iman sebagai sebuah bentuk cara pandang metafisis yang diilhami agama akan membawa pada pemahaman yang mendalam tentang kejadian-kejadian evolutif. Baginya, apapun konsep dan pemahaman tentang sains, seorang saintis selalu dibentuk oleh pandangan umum relitas (general vision of relity) yang ia miliki, yakni metafisika, dan kandidat terkuat adalah konsep teologis. "this theological metaphysics is superior to the materialist alternative"(Haught, 2004). Jadi usulan Haught adalah untuk menjadikan teologi (agama) sebagai landasan atau akar sains. Diatas landasan inilah integrasi bisa terwujud. Jika digambarkan dalam batang tubuh sebuah pohon, maka teologi (agama) adalah akar sedangkan batangnya adalah struktur sains.

3. Bentuk Integratif Sains dan Agama (Theology of Evolution)

Setelah melihat pola integrasi yang terbangun antara sains dan agama, Haught mencoba lebih konkrit lagi dengan menelaah terintegrasikannya teori evolusi dan agama (teologi) yang ia sebut teologi evolusi (theology of evolution). Ini adalah respon atas minimnya tinjauan teologis dalam evolusi. Dalam banyak pandangan agamawan, teori evolusi dituduh sebagai sebuah kekuatan yang paling berbahaya bagi eksistensi agama. Namun dibalik kekhawatiran itu kekritisan untuk membawa teori evolusi dalam perspektif teologis masih sangat minim. Di sinilah Haught dengan berani menawarkan pembacaan yang sangat eksploratif, yakni bagaimana menggiring teori evolusi hingga ia bermuatan teologi.
Kritisisme Haught mengantarkannya pada teori evolusi adalah karena perkembangan evolusi yang cukup ekstrim. Saat ini biologi menjadi benteng materialisme. Seperti dikutip Haught, Michel Russel mengatakan bahwa Darwinisme adalah penjelmaan tersempurna dari teori materialism (Haught, 2003). Lebih jauh teori Darwin secara dramatis, berbeda dengan perkembangan sains modern lain, telah mendorong ditempatkannya agama semata-mata dalam ruang ilusi yang tidak mempunyai akar kebenaran. Dan tidak ada teori yang begitu mengancam pemahaman tentang kebertuj-uan alam semesta kecuali teori evolusi. Yang menjadi perhatian Haught adalah bagaimana membaca atau menginterpretasi teks-teks kitab suci dalam cahaya Darwinian. Ia paparkan dalam God After Darwin bahwa evolusi biologi bukan hanya tidak bertenta-ngan dengan agama akan tetapi lebih dari itu ia juga pemberian berharga bagi teologi. Ini disebabkan munculnya pemahaman tentang Tuhan yang relatif tidak persis sama seperti sebelum adanya teori Darwin dan di lain pihak evolusi tidak serta merta mengurangi iman adanya kekuatan kreatif ilahiah. Dengan sangat meyakinkan Haught menega-skan bahwa: "Darwin has gifted us with an account of life whose depth, beauty, and pathos-when seen in the context of the larger cosmic epic of evolution-expose us afresh to the raw reality of the sacred and to a resoundingly meaningful universe".

Suatu bagian yang membuat evolusi tidak harmonis dengan ide tentang Tuhan bukan karena berita mengejutkan Darwin tentang proses seleksi alam, namun karena ketidakmampuan teologi merefleksi secara mendalam tentang penderitaan dalam dimensi ilahiah. Pemahaman tentang Tuhan sebagai sumber keteraturan / ketertiban (source of order) yang menentukan segala kejadian yang ada di alam semesta tidak lagi bisa memberi kepuasan. Haught menawarkan pembacaan tentang Tuhan bukan semata sebagai zat yang mengatur segala sesuatu agar berjalan sesuai dengan fungsinya akan tetapi ia juga dipahami sebagai bentuk munculnya ketidakharmonisan. Lebih lanjut kosmos tidak melulu diartikan dalam kerangka keberaturan (order) akan tetapi juga dipandang sebgai sebuah proses yang belum selesai (unfinished process), dimana alam semesta masih dalam proses menjadi. Sedangkan posisi Tuhan tidak 
lagi dalam kerangka kemahakuasaan (dalam makna yang literal) dimana tidak secara langsung turun dalam proses penciptaan, namun memberi ruang agar proses alamiah bisa berjalan di dalamnya. Andaikan pemahaman semacam itu ada, maka antara sains dan teologi tidak akan bertentangan. Dengan itu pula konsep tentang Tuhan tidak hanya akan dipandang sesuai dengan perkem-bangan sains kontemporer akan tetapi juga secara logis mengantisipasi penjelasan Darwin tentang kehidupan sebelum adanya manusia.

Bagi Haught teori evolusi adalah sebuah cahaya yang mampu menerangi dan akhirnya menemukan makna yang lebih dalam tentang agama dan Tuhan. Bahkan ia menyebut teori evolusi sebagai intuisi terdalam (deepest intuition) karena dengan cahaya envolusi tersebut akan membawa teologi melangkah lebih jauh dalam memahami "realitas tertinggi" (ultimate reality). Ia menggambarkan relasi agama dan evolusi sebagai "engagement" dimana pemikiran Darwin dipandang bukan sebagai ide berbahaya (dangerous idea) bagi pemahaman teologi. Sebaliknya ia ditempatkan sebagai sumber untuk merefleksi makna hidup, Tuhan, dan alam semesta. Ada dua dampak yang secara signifikan mempengaruhi teologi; pertama, munculnya pemaknaan baru tentang karakter "natural theology" (sebuah pencarian akan bukti-bukti eksistensi Tuhan di alam semesta). Bentuk nyata dari natural theology adalah munculnya teori "desain cerdas" (intelligent design), teori yang menyatakan bahwa proses penciptaan telah didesain sedemikian rupa sehingga memunculkan kehidupan. Struktur dasar penciptaan telah menyediakan perangkat substansial sehingga tumbuhan, manusia, dan segala bentuk kehidupan bisa berlangsung, hanya saja pandangan ini tidak membawa pemahaman baru tentang pengaruh signifikan teori evolusi terhadap teologi. Intelligent design tidak memperhitungkan dimensi kebetulan (contingency), keacakan (randomness), dengan perjuangan (struggle) akan evolusi.

Oleh sebab itu Haught menaruh perhatian besar pada efek kedua, yakni "evolutionary theology." Satu konsep yang mengalami pengayaan karena perjumpaannya dengan teori evolusi adalah pemahaman tentang kekuasaan Tuhan (divine power). Haught menggunakan teologi proses (process theology) untuk memaknai proses evolusi dimana evolusi hadir sebagai bentuk awal penciptaan karena kekuasaan Tuhan dan tindakannya terhadap dunia diambil dalam sikap yang persuasif (persuasive love) ketimbang kekuasaan yang memaksa. Kuasa Tuhan tidak bersifat memaksa akan tetapi mengundang, karena jika memaksa akan bertentangan dengan sifat alami cinta (the very nature of love). Pilihan atas dasarnya jika kekuasaan dimaknai sebagai,,kapasitas untuk mempengaruhi" maka pendekatan persuasif jauh lebih efektif dari pada pendekatan pemaksaan atau kekerasan. Dari sini secara jelas diketahui bahwa sosok Haught adalah teolog yang mencoba mengintegrasikan sains (teori evolusi) dengan agama.

4. Titik Temu Pemikiran John F. Haught dalam Konstruksi Sains dan Agama

Dalam konteks hubungan sains dan agama, letak metafisika ada pada struktur epistemologis sains yang berfungsi sebagai landasan bagi eksistensi sains. Bentuk konkrit dari metafisika adalah iman (faith). Ibarat sebuah pintu, keimanan adalah kunci yang memungkinkan manusia menjelajah lebih jauh ke dalam sebuah rumah. Oleh sebab itu keimanan berfungsi sebagai langkah pertama yang harus dilalui untuk menguak rahasia realitas. Melalui keimanan kesadaran manusia mengenal keterbatasannya dan saat yang bersamaan mengantar pada pengetahuan atas dimensi yang lebih tinggi atau dimensi yang lebih mendalam.

Dalam ekplorasi ilmiah seorang saintis harus berkomitmen pada keyakinan bahwa "alam semesta dapat dipahami (the universal is intelligible)" atau "kebenaran perlu dicari (truth is worth seeking)" (Bairizki, 2021). Menurut Haught komitmen keyakinan saintifik tersebut mempunyai kesesuaian dengan visi keagamaan. Dan sains mempunyai makna yang lebih dalam jika dipadukan dengan konteks keagamaan. Kerangka teologis metafisik (theological metaphysical framework) ini akan membawa penemuan-penemuan sains lebih bisa dimengerti (intelligible).

Haught dengan sangat jelas mengartikan metafisika sebagai visi umum (general vision) dalam melihat sesuatu, sehingga menempatkan agama sebagai bangunan yang bisa masuk ke dalamnya. Agama yang membawa prinsip-prinsip umum memberi pengaruh pada bagaimana sains harus dimaknai. Namun klaim Haught bahwa agama adalah entitas terkuat untuk bisa menjadi 
kerangka sains (evolusi) dibantah oleh Richard Dawkins. Bagi Dawkins, semenjak ditemukannya teori evolusi agama tidak lagi mempunyai tempat yang signifikan dalam bangunan sains (khurusnya teori evolusi). Seleksi alam yang diinterpretasi Dawkins sebagai pembuat jam buta (blind watchmaker), buta karena sifatnya yang tidak melihat ke depan dan tidak berjuang adalah bukti bahwa tidak adap peran agama di sana. Pandngan agama bahwa semesta ini bertujuan dimana semuanya ada dalam kekusaan Tuhan tidak lagi signifikan. Bagi Ellis apa yang dilakukan Dawkins telah keluar dari wilayah sains karena ia telah melakukan justifikasijustifikasi yang bersifat metafisis filosofis.

Hal ini pula yang dituduhkan Haught, dimana hal semacam itu dikategorikan sebagai saintisme. Apalagi sejak awal Dawkins memposisikan teori evolusi berlawanan dengan agama. Upayanya yang mencoba mencari jawaban yang sama (tentang ultimate explanation) adalah pandangan yang berlebihan dan melebihi wilayah sains. Apa yang dilakukan Dawkins dilandasi oleh semangat yang luar biasa untuk menjatuhkan agama yang akhirnya membawa keduanya pada wilayah-wilayah yang seharusnya melibatkan, secara serius, metafisika, filsafat, bahkan agama.

Penegasan Haugth bahkan pemahaman terhadap sains harus disertai oleh konsep teologis muncul karena baginya bangunan teologis tersebut lebih unggul atau memuaskan dari pada penjelasan-penjelasan yang ditawarkan materialisme. Ada dua hal mendasar mengapa metafisika dengan muatan teologis mempunyai kerangka yang lebih mendalam, yakni, pemahaman tentang kekuasaan (power) dan dimensi kekuasaan ketika dihubungkan dengan sifat otonomi evolusi sains. Di sini, ia menyontohkan karakter kerendahan hati Tuhan (the humility of God) sebagai karakter teologis yang memungkinkan kebaruan (novelty) yang benar (true) muncul secara spontan. Ini bertentangan dengan pandangan kaum materialis yang mamaknai fenomena tersebut secara deterministik. Haught juga tidak sepakat dengan pandangan yang melihat semesta sebgai hamparan yang bersifat abadi dan tetap (fix).

Dari uraian di atas terlihat bahwa bangunan teologis yang ditawarkan Haught adalah bangunan teologis yang terilhami oleh teori evolusi sehingga bangunan teologis yang bersifat tidak evolutif bukan menjadi bangunan ideal teologi. Bangunan teologis tak berkarakter evolusi ini biasanya tergambar pada "intelligent design". Tokoh lain yang melihat teologi sebagai jalan keluar bagi sains adalah Richard Swinburne. Baginya, apa yang ditawarkan Darwin tentang kompleksitas organisme sebagai buah dari proses evolusi mempunyai sisi kebenaran, akan tetapi itu bukanlah sebuah penjelasan utama bahwa sesuatu terjadi karena sesuatu yang lain. Lebih jelas lagi ia menguraikan rangkaian terjadinya teori evolusi; teori evolusi adalah konsekuensi dari hukum kimiawi yang memungkinkan adanya makhluk hidup. Hukum kimia tersebut adalah konsekuensi munculnya penyusunan kimiawi sehingga memunculkan kehidupan yang harus eksis? Jika hukum fisika tidak membuka kemungkinan terjadinya proses penyusunan kimiawi sehingga memunculkan potensi kehidupan, maka kehidupan tidak akan pernah ada. Dan jika tidak ada proses variasi acak yang muncul dari sifat-sifat orang tua, maka tidak akan pernah ada teori evolusi. Bagi kalangan materialis, pertanyaan dan Kenyataan semacam itu tidak mempunyai jawaban. Sedang bagi kaum agamawan, fenomena itu meyakinkan bahwa Tuhan mempunyai alasan yakni agar hewan dan manusia terus berkembang.

Pernyataan Swinburne bahwa hadirnya Tuhan bukan sekedar sebagai pengisi rongga kosong yang ditinggalkan sains menunjukkan bahwa relasi antara sains dan Tuhan tidak bersifat sekedar isi mengisi. Namun untuk bisa memahami realitas secara utuh maka kehadiran kedua-duanya diperlukan. Dan pola semacam ini mempunyai kesamaan dengan idealisme Haught untuk melengkapi sains dengan dimensi teologis. Pandangan Haught tentang landasan integrasi sains dan agama mempunyai kesamaan dengan pemikiran Golshani terutama tentang makna dan fungsi metafisika. Golshani sering menyebut metafisika bersandingkan dengan wordview, sebuah kata yang mempunyai arti yang sama dengan visi umum (general vision) atau cara pandang. "A wordview is a framework within which our minds operate. It includes our metaphysical and epistemological presuppositions about God, the universe and humanity. Our worldview affects our decisions, priorities, values and goals. It brings our thoughts to a unified whole". 
Yang menjadi perhatian utama Mehdi Golshani adalah sains tidak pernah bisa bersifat netral tanpa dipengaruhi oleh cara pandang yang dimiliki oleh seorang saintis. Ia menjelaskan dengan mendalam bagaimana sains tidak bersifat netral atau bebas nilai. Sains selalu dipengaruhi oleh kecenderungankecenderungan yang dimiliki oleh seorang saintis. Disini ia mengategorikan ruang tersebut sebagai praduga metafisis (metaphysical presupposition). Ia membantah pandangan yang mengatakan bahwa jika sains bisa dimasuki oleh ideologi, agama, atau nilai-nilai lain yang diluar struktur sains maka sains tidak bersifat universal lagi.

\section{SIMPULAN DAN SARAN}

\section{A. Simpulan}

Berdasarkan pemaparan pada penelitian ini dapat disimpulkan bahwa Agama dan sains, merupakan dua bagian penting dalam kehidupan sejarah umat manusia. Bahkan pertentangan antara agama dan sains tak perlu terjadi jika kita mau belajar mempertemukan ide-ide spiritualitas (agama) dengan sains yang sebenarnya sudah berlangsung lama. Dalam integrasi agama dan sains, perlu diupayakan dengan konflik, kontras, kontak, dan konfirmasi. Artinya, sains tidak mengarahkan agama kepada jalan yang dikehendakinya dan begitu juga agama tidak memaksanakan sains untuk tunduk pada kehendaknya. Agama harus membantu sains dengan memberikan perspektif yang berbeda. Sains harus membantu agama untuk melihat kehidupan yang berbasiskan pengalaman empiris. Kita tidak perlu menganjurkan sains untuk berubah-ubah pandangan. Di lain pihak, kita perlu mengingatkan agama (agamawan) untuk bersedia berubah sesuai dengan perkembangnya pengetahuan. Dalam pandangan Haught sains tidak bisa memenuhi dirinya sendiri (self sufficient) dalam melakukan upaya-upaya ilmiah. Sains selalu merujuk atau mengakar pada keimanan (faith). Bagi Haught teori evolusi adalah sebuah cahaya yang mampu menerangi dan akhirnya menemukan makna yang lebih dalam tentang agama dan Tuhan.

\section{B. Saran}

Pembahasan terkait penelitian sumbangan pemikiran Jhon $F$ Haught mengenai relasi sains dan agama dalam penelitian ini masih sangat terbatas dan membutuhkan banyak masukan. Saran untuk penulis selanjutnya adalah mengkaji lebih dalam dan secara komprehensif terkait sumbangan pemikiran Jhon $\mathrm{F}$ Haught mengenai relasi sains dan agama serta studi kritis terhadap Jhon $\mathrm{F}$ Haught mengenai Agama dan sains.

\section{DAFTAR RUJUKAN}

Abidin. (2005). Islam, Science and Islamic Science: How to Integrate Science and Religion. In Science and Religion in PostColonial World. Australia: ATF Press.

Arifudin, O. (2020). Manajemen Risiko. Bandung : Widina Bhakti Persada.

Arifudin, 0. (2021). Manajemen Strategik Teori Dan Implementasi. Banyumas: Pena Persada.

Asmedy, A. (2021). Perbandingan Hasil Belajar Matematika Siswa yang diajar dengan Model Pembelajaran Possing Problem Berkelompok dan Metode Ceramah. Jurnal Inovasi, Evaluasi Dan Pengembangan Pembelajaran (JIEPP), 1(2), 69-75. https://doi.org/10.54371/jiepp.v1i2.107

Bahri, A. S. (2021). Pengantar Penelitian Pendidikan (Sebuah Tinjauan Teori dan Praktis). Bandung : Widina Bhakti Persada.

Barbour. (2000). When Science Meets Religion. New York: HarperSan-Francisco.

Barbour. (2006). Isu dalam Sains dan Agama, terjemahan Damayanti dan Ridwan. Yogyakarta: UIN Sunan Kalijaga Press.

Febrianty, F. (2020). Kepemimpinan \& Prilaku Organisasi Konsep Dan Perkembangan. Bandung: Widina Bhakti Persada.

Hanafiah, H. (2021). Pelatihan Software Mendeley Dalam Peningkatan Kualitas Artikel Ilmiah Bagi Mahasiswa. Jurnal Karya Abdi Masyarakat, 5(2), 213-220.

Hasbi, I. (2021). Administrasi Pendidikan (Tinjauan Teori Dan Praktik). Bandung: Widina Bhakti Persada.

Haught. (1995). Science and Religion: In Search of Cosmic Purpose. New York: Paulist Press. 
Haught. (2000). Science and Religion: from Conflict to Conversation. New York: Paulist Press.

Haught. (2003). Deeper Than Darwin: The Prospect for Religion in the Age of Evolution. New York: Westview Press.

Haught. (2004). Seeing the Universe: Ian Barbour and Teilhard de Chardin. In Russel, Robert John ed. Fifty Years in Science and Religion. England: Asghate.

Haught. (2004). The Promise of Nature: Ecology and Cosmic Purpose. New York: Wipf \& Stock Publishers.

Irwansyah, R. (2021). Perkembangan Peserta Didik. Bandung : Widina Bhakti Persada.

Jamaah, J. (2021). Peran Guru dalam Pembelajaran Home visit di Masa Pandemi Covid-19 pada Siswa Sekolah Dasar. Jurnal Inovasi, Evaluasi Dan Pengembangan Pembelajaran (JIEPP), 1(1), 1-10. https://doi.org/10.54371/jiepp.v1i1.74

Juhji. (2020). Manajemen Humas Sekolah. Bandung: Widina Bhakti Persada.

Leksono. (2003). Cosmology and the Human Endless Search for Meaning. International Conference on "Religion \& Science in the Post-Colonial World". Yogyakarta: Center for Religious and Cross-cultural Studies UGM dan Templeton Foundation USA.

Marantika, N. (2020). Manajemen Humas Sekolah. Bandung: Widina Bhakti Persada.

Mayasari, A. (2021). Implementasi Sistem Informasi Manajemen Akademik Berbasis Teknologi Informasi dalam Meningkatkan Mutu Pelayanan Pembelajaran di SMK. JIIPJurnal Ilmiah Ilmu Pendidikan, 4(5), 340345. https://doi.org/10.54371/jiip.v4i5.277

Na'im, Z. (2021). Manajemen Pendidikan Islam. Bandung: Widina Bhakti Persada.
Nasser, A. A. (2021). Sistem Penerimaan Siswa Baru Berbasis Web Dalam Meningkatkan Mutu Siswa Di Era Pandemi. Biormatika: Jurnal Ilmiah Fakultas Keguruan Dan Ilmu Pendidikan, 7(1), 100-109.

Nurhasanah, E. (2021). Peran Orang tua dalam Membimbing Anak Usia Sekolah Dasar di Rumah pada Masa Pandemi Covid-19. Jurnal Inovasi, Evaluasi Dan Pengembangan Pembelajaran (JIEPP), 1(1), 11-18. https://doi.org/10.54371/jiepp.v1i1.75

Rahayu, Y. N. (2020). Program Linier (Teori Dan Aplikasi). Bandung : Widina Bhakti Persada.

Rinjani, C., Wahdini, F. I., Mulia, E., Zakir, S., \& Amelia, S. (2021). Kajian Konseptual Model Pembelajaran Word Square untuk Meningkatkan Hasil Belajar Siswa.Jurnal Inovasi, Evaluasi Dan Pengembangan Pembelajaran (JIEPP), 1(2), 52-59. https://doi.org/10.54371/jiepp.v1i2.102

Sofyan, Y. (2020). Peranan Konseling Dosen Wali Dalam Meningkatkan Motivasi Belajar Mahasiswa Di Perguruan Tinggi Swasta Wilayah LLDIKTI IV. Jurnal Bimbingan Dan Konseling Islam, 10(2), 237-242.

Sugiyono. (2015). Metode Penelitian Pendidikan (Pendekatan Kuantitatif,. Kualitatif dan $R \& D)$. Bandung : CV. Alfabeta.

Tanjung, R. (2020). Analisis Pengaruh Penilaian Kinerja Dan Kompensasi Terhadap Produktivitas Kerja Pada PDAM Kabupaten Karawang. Jurnal Ilmu Manajemen, 10(1), 71-80.

Waston. (2014). Hubungan Sains Dan Agama: Refleksi Filosofis Atas Pemikiran Ian G. Barbour. Profetika, Jurnal Studi Islam, 15(1), $76-89$. 